\title{
Januário: Jano ou homo sacer
}

Josalba Fabiana dos Santos Universidade Federal de Sergipe

Resumo: A partir do episódio da morte em efigie da personagem Januário, de Os sinos da agonia (1974), romance de Autran Dourado ambientado nas Minas Gerais do século XVIII, o presente trabalho discute aspectos relacionados ao duplo, adotando principalmente as perspectivas de Clément Rosset e de Gilles Deleuze. Problematizando a aproximação mais ou menos evidente entre o rapaz e o deus Jano da mitologia romana, este texto apresenta Januário como um homo sacer, no sentido que Giorgio Agamben dá a essa expressão em livro homônimo. O homo sacer é uma pessoa insacrificável e matável. Sendo assim, torna-se possivel afirmar que Januário morre em efígie porque ele é abandonado pela sociedade e a sociedade o abandona para poder matá-lo.

Palavras-chave: Os sinos da agonia, Duplo, Homo sacer.

\section{Introdução}

Januário, um dos protagonistas de Os sinos da agonia (1974), de Autran Dourado, tem um nome e algumas características que o aproximam do mitológico deus Jano. Iniciar e finalizar algo é uma delas, olhar em várias direções é outra e a duplicidade provavelmente é a principal. Todavia, as semelhanças existentes também se abrem para diferenças fundamentais entre eles, pois, 
segundo Deleuze, mesmo "a mais rigorosa repetição, tem, como correlato, o máximo de diferença". No decorrer da leitura aqui proposta, Januário se distancia do deus para se aproximar de uma categoria mais condizente com o seu perfil e com os acontecimentos que se desenvolvem no romance, o homo sacer. Centro da discussão feita por Giorgio Agamben em livro homônimo, o bomo sacer seria um sujeito insacrificável e matável. Januário transita das características do deus Jano para aquelas que o prendem - e o matam - na condição de homo sacer.

Os sinos da agonia é um romance ambientado em Vila Rica, nas Minas Gerais de fins do século XVIII, e conta a história da jovem e ambiciosa Malvina, que se casara com João Diogo, homem já bastante idoso, para ascender socialmente. Entretanto, ao conhecer Gaspar, filho de João Diogo, ela se apaixona perdidamente. Para realizar seu amor incestuoso, segundo os padrões morais da época, Malvina toma Januário como seu amante e o convence a matar o marido indesejado. É quando se inicia a ilusão de Januário, pois no triângulo amoroso, ocupado por Malvina, João Diogo e Gaspar, ele está à margem, mas demora a perceber isso. Somente ao final da narrativa o rapaz se dará conta da pequenez do seu papel, quando se compara ao marido indesejado da amante: "Ele próprio se sentia mulher, os gestos amaricados, musicais. Começava a se aflautar, doce. Tinha ódio do que ela fez dele. Dele, de João Diogo Galvão [...] Todos tinham sido joguetes nas mãos diabólicas de Malvina" ${ }^{2}$. Ao final do romance, Januário admite ter sido apenas "Um boneco nas suas mãos"

As aproximações feitas entre Januário e um boneco são inúmeras. Na verdade, sobre o seu relacionamento com Malvina, as comparações são com um boneco, um qualquer e indefinido boneco. Porém, essa metáfora adquire contornos bem mais complexos e macabros quando o rapaz é morto em efígie. Ou seja, um boneco é confeccionado, a efígie, para "morrer" no seu lugar.

\section{O deus e o mortal}

Inicialmente é preciso explicar quem é o deus que será comparado na sequência a Januário:

1. DELEUZE. Diferença e repetição, p. 39.

2. DOURADO. Os sinos da agonia, p. 317.

3. DOURADO. Os sinos da agonia, p. 317. 
Jano é um dos mais antigos deuses do panteão romano. É representado com dois rostos que se opõem, um olhando para a frente, outro para trás. As lendas sobre Jano são unicamente romanas e ligadas às origens da cidade. Segundo alguns mitógrafos, Jano era indígena de Roma, onde teria outrora reinado com Câmeses, um rei mítico de quem nada se sabe além do nome. Segundo outros, Jano era um estrangeiro, originário da Tessália e exilado em Roma, onde teria sido recebido favoravelmente por esse Câmeses, que teria partilhado o seu reino com ele. ${ }^{4}$

Dois reis para um único reino é algo inusitado e, de certa forma, revela o poder conciliador de ambos. Essa divisão do reino também se adéqua muito bem a um deus duplo, dividido em duas faces.

Pierre Grimal diz ainda que Jano era um "mestre na arte de ver para a frente e para trás (isto é, examinar as questões em todos os seus aspectos)", o que combina muito bem com a primeira citação. Essa imagem evidencia claramente que Jano é um duplo por excelência: dois rostos remetem a dois olhares, a duas maneiras de ver o mundo e a diferentes formas de ser. E aí paira a definição do duplo, ser "o mesmo e um outro", o que consiste num paradoxo evidente - como um pode ser dois? No entanto, Jano é um deus. O seu rosto dobrado possibilita que ele seja dois. Um olhar vai para o passado e o outro, para o futuro. Um rosto vê o que não é mais, enquanto o outro se abre em perspectiva, observando o futuro, o que possibilitaria uma visão bastante ampla sobre qualquer acontecimento ou pessoa. Isso para não mencionar que duas faces implicam duas ou mais personalidades. Jano é assim um deus de fronteira, de transição. Ele marca a passagem do tempo e a passagem das pessoas e coisas no tempo, inclusive alterações dele próprio, inapreensíveis a um seu observador, que nunca o vê integralmente. Logo, Jano é associável a transformações.

Raquel Faustino, em artigo intitulado "A origem do universo em Ovídio", 7 afirma, a partir da leitura do poeta latino, que Jano era o Caos, uma massa disforme que teria possibilitado o início do universo. Com o passar do tempo, o ar, a terra, o fogo e a água deixaram de ser elementos concorrentes e conflituosos e passaram, cada um, para o espaço hoje ocupado. Foi então que o próprio deus Jano emergiu do Caos que era, essa massa disforme que continha

4. GRIMAL. Dicionário da mitologia grega e romana, p. 258.

5. GRIMAL. Dicionário da mitologia grega e romana, p. 259.

6. ROSSET. O real e seu duplo: ensaio sobre a ilusão, p. 33.

7. FAustino. A origem do universo em Ovídio, p. 266-268. 
os quatro elementos, e se tornou um corpo humano com duas faces. Januário, o personagem de Os sinos da agonia, também é composto a partir de uma mistura:

A mãe mameluca, do mesmo bronze da sua cor. Diziam que ela era bugra. O nome soava como uma ofensa. Não a ela, a ele que o confundia com outra coisa. Sou bugra não, minha mãe é que era, pegada a laço, dizia. Filha de branco com cunhã neófita puri. Ele meio puri antes, agora cada vez mais puri. A mãe teúda e manteúda, feito diziam. O pai, Tomás Matias Cardoso, homem rico, quase um potentado, morava com sua mulher Joana Vicênzia e mais quatro filhos brancos (não eram que nem ele, eram brancos de geração) $[. . .]^{8}$

Assim como o deus Jano advém do Caos, da mistura de elementos, Januário advém de uma mistura, no caso, de raças. A mistura de onde provém Jano, um deus, lhe é proveitosa, mas a mistura de onde provém Januário, não. Afinal, o rapaz não é um deus, ele é apenas um homem vivendo no Brasil, na Vila Rica do final do século XVIII. Januário vive numa sociedade patriarcal e escravocrata, portanto segregadora, uma sociedade regida por brancos. Ele não é branco nem índio, é mestiço: um homem livre destituído de posses. Ele é filho de um branco com uma mameluca, que por sua vez era filha de um branco com uma índia. Seu pai é Tomás Matias Cardoso, sua mãe é apenas mãe Andresa. O pai tem nome e sobrenome, a mãe só tem o primeiro nome. O pai é um senhor rico e casado; a mãe fora a amante, a amásia desse mesmo homem. Logo, Januário não passa de um filho bastardo que nem sequer chama Tomás Matias Cardoso de pai na presença de estranhos. Porém, como se verá adiante, o poder do pai, um potentado, não será suficiente para proteger o rapaz das forças que irão destruí-lo.

Retomando ainda uma vez as palavras de Grimal, observamos que "ver para a frente e para trás" também pode suscitar indecisão, dúvida. Jano está marcado pelo excesso, pois vê demais. Mas Jano é um deus, assinalado pela sabedoria, capaz de controlar e selecionar ou mesmo ficar imune às possíveis mazelas causadas por esse excesso de conhecimento. Infelizmente, Januário, o personagem de Os sinos da agonia, não é um deus, ele é um mortal com algumas características divinas. Januário guarda semelhanças com Jano, mas não tem a sua imortalidade. O rapaz tem esse olhar que se dirige em todas as direções, mas isso o confunde. O deus Jano encerra em si o poder de tudo saber e de tudo ver; ele,

8. DOURADO. Os sinos da agonia, p. 16-17. 
como Januário, é um duplo. Porém, enquanto a duplicidade do deus se coloca em termos de saber e ver em dobro, em Januário essa mesma duplicidade se coloca em termos de indecisão, de dúvida e de divisão. O rapaz está diante de um impasse: a ilusão que embalou sua paixão e a realidade que lhe é cruel. Boa parte do romance é dedicada ao reconhecimento desse real. Um "real [que] não voltará jamais, porque já está aî”. Por isso Januário apenas o reconhece. Segundo Rosset:

A técnica geral da ilusão é, na verdade, transformar uma coisa em duas, exatamente como a técnica do ilusionista, que conta com o mesmo efeito de deslocamento e de duplicação da parte do espectador: enquanto se ocupa com a coisa, dirige o seu olhar para outro lugar, para lá onde nada acontece.

Januário é o ilusionista que engana a si próprio, que dobra a realidade para ser feliz com sua amante, criando a ilusão de ser amado, pelo menos até reconhecer o logro.

Há ainda mais um aspecto a aproximar o deus do mortal. "Janeiro", a palavra que designa o primeiro mês do ano, tem sua origem etimológica em Jano; janeiro recebeu esse nome em sua homenagem. ${ }^{11}$ Janeiro é o início de um ano, o que pressupõe o fim do anterior. Por isso Jano é um deus de passagem, que marca o início de algo e consequentemente o final de alguma outra coisa. Janeiro também remete à circularidade: em todos os anos o mês se repete no mesmo momento, o início. Mas o que ocorre em janeiro não é repetição, é diferença, fazendo com que a circularidade sempre se insinue sem jamais se completar totalmente. Ou seja, não se trata de um círculo e sim de uma espiral. O movimento é circular, mas, a cada volta completa que se dá, é em outro ponto que se toca. Deleuze explica que "O problema do começo em filosofia foi sempre considerado, com razão, como muito delicado, pois começar significa eliminar todos os pressupostos". ${ }^{12}$ Dito de outro modo, o começo implicaria um essencialismo que não parece muito compatível com as representações geométricas feitas. Além disso, como afirma ainda Deleuze, "a imagem do círculo daria testemunho, antes de tudo, de uma impotência para começar verdadeiramente e também para repetir autenticamente". ${ }^{13}$

9. ROSSET. O real e seu duplo: ensaio sobre a ilusão, p. 14, grifo do original.

10. ROSSET. O real e seu duplo: ensaio sobre a ilusão, p. 18, grifo do original.

11. FAUSTINO. A origem do universo em Ovídio, p. 267.

12. DELEUZE. Diferença e repetição, p. 225.

13. DELEUZE. Diferença e repetição, p. 226. 
Assim, a etimologia nos ajuda a estabelecer uma relação clara com o personagem de Os sinos da agonia. "Januário" é januarius ou ianuarius em latim. Januarius em português formou "janeiro", o primeiro mês do ano. Januarius do latim deriva de Janus, que em português é "Jano". É assim que "Januário" se encontra com o deus, etimologicamente falando. Mas é aí mesmo onde eles se encontram que também ocorre o distanciamento. Na aproximação com janeiro, o suposto começo, o início, seria o caso de pensar na ingenuidade que rege os atos e pensamentos de Januário. Sua falta de conhecimento o condenará a uma vida de enganos. Porém, esse mesmo começo ao qual o rapaz está aparentemente condenado não é um começo no nada. Sempre há um antes e um depois.

No romance de Autran Dourado é Januário quem abre a narrativa e também a encerra. O livro é dividido em quatro jornadas. A "Primeira jornada", denominada "A farsa", é toda dedicada a Januário. Na "Segunda" e na "Terceira", seu papel é secundário. Porém, na "Quarta jornada", denominada "A roda do tempo", ele retorna, ele se repete como o mês de janeiro no calendário e, como o próprio título indica, ele roda. A "Quarta jornada" é subdividida em três partes, cada uma dedicada ao arremate da história de um personagem diferente. Januário está presente na última parte, a terceira, da "Quarta jornada". Portanto, ele abre e fecha o romance. Januário, como o deus Jano, é a porta de entrada e a porta de saída.

Mas a narrativa não é posta em ordem cronológica para o leitor. Na "Primeira jornada - A farsa" - João Diogo, o marido de Malvina, fora assassinado por Januário havia um ano. Portanto, o leitor é posto in medias res. No fundo, a primeira parte não começa nada além do livro, porque a história propriamente dita já começou. Ora, se a história já se iniciou, no rigor do termo, Januário não abre a narrativa, pois ela já estava lá: acontecendo e acontecendo de novo. E assim se tem duas indicações bastante claras do universo do teatro: porque o recurso in medias res era frequentemente utilizado nas tragédias da Antiguidade Clássica e porque farsa é um tipo de representação teatral cômica. À primeira vista pode parecer inusitada uma relação entre farsa, uma peça cômica, e o conteúdo do romance de Autran Dourado, muito mais próximo de uma tragédia clássica, estabelecendo uma evidente intertextualidade com Hipólito, de Eurípedes (discussão já feita pela crítica). A "Primeira jornada" narra justamente uma farsa, no sentido de embuste, engano, logro. Um embuste que poderia ter sido cômico, mas não foi. A farsa que esse capítulo inicial conta é a da morte em efígie de Januário. 


\section{A morte em efígie}

A efígie é a representação da imagem de alguém real ou não. No caso da morte em efígie, o condenado é substituído inicialmente por uma imagem. Essa substituição é, em termos, provisória, porque uma vez que o sujeito foi morto em efígie, estará morto jurídica e socialmente, pois ele é o:

[...] réo q. se proclama morto p. a a verdade civil, podendo assim os seus bens serem filhados por qualquer q. os queira; e mesmo o seu corpo de facto, se encontrado, e cuja busca se recomenda, pode sofrer consumição p. a sempre por bala, punhal, espada, catana, mãos ou quaesquer peças mortíferas, sem q. ao seu auctor se lhe possa se-quer imputar a pecha de criminoso, antes pelo contrário muy digno e merecedente da estima de El-Rey e de Seus magnânimos favores, bem como de Seus delegados e ministros [...] ${ }^{14}$

Quem morre em efígie tem uma morte representada. O que morre na morte em efígie é um símbolo, uma imagem, uma figura ou um retrato de alguém. A morte em efígie é o teatro da morte de uma determinada pessoa que se quer morta. A morte em efígie é uma farsa no duplo sentido dessa palavra: como peça cômica, porque guarda em si um quê de ridículo, e como logro e embuste. Entrega-se à morte algo que não é o sujeito que deveria estar morto; assim, a morte é lograda. Em termos, porque o sujeito representado na farsa está simbolicamente morto. A morte só precisa aguardar pelo corpo verdadeiro que substituirá o corpo falso, o corpo da farsa. O sujeito representado na morte em efígie está morto socialmente; para todos os efeitos, ele já não existe. Morta sua representação, o sujeito está morto, torna-se um fantasma de si próprio, um vivo-morto, um duplo. É nesse duplo de si próprio que se transformou Januário.

Antes mesmo da "Primeira jornada - A farsa" -, a morte em efígie é anunciada nas quatro epígrafes que antecedem a narrativa de Os sinos da agonia. A primeira epígrafe, retirada dos Capítulos de história colonial, de Capistrano de Abreu, fala de alguém que "padeceu o suplício em efígie", ${ }^{15}$ sem dizer a quem exatamente se refere. Na segunda epígrafe, retirada da História antiga das Minas Gerais, de Diogo de Vasconcelos, explica-se o que seria:

14. DOURADO. Os sinos da agonia, p. 35 .

15. ABREU apud DOURADO. Os sinos da agonia, p. 7. 
A morte em efígie, ainda que farsa, tinha todas as consequências da natural. Seguia-se dela a servidão e a infâmia da pena e o confisco dos bens. Não aproveitava em circunstância alguma ao réu a esperança do perdão; e quem o quisesse poderia matar sem receio de crime. ${ }^{16}$

Portanto, a morte em efígie - a farsa, não por acaso o título da "Primeira Jornada" - era uma sentença, aplicada quando, por algum motivo, o réu se colocava distante dos braços da lei. Em outras palavras, quando alguém cometia um crime muito grave e fugia, essa pessoa era morta simbolicamente. Na ausência do condenado, o Estado aplicava a pena de morte a um boneco. E a farsa que a morte em efígie gerava tinha o poder de matar socialmente o condenado. A morte em efígie gerava o fim do réu. Seus bens, se bens houvesse, ficavam disponíveis a qualquer pessoa. Nada do que lhe pertencia ou pertencera, visto que estava "morto", poderia ser por ele vendido. Januário, após matar João Diogo e fugir, é sentenciado a sofrer uma morte em efígie. Acontecimento que se realiza com grande pompa. Passado um ano, ele decide voltar a Vila Rica e se entregar. É esse o momento da narrativa da "Primeira jornada - A farsa". Sempre acompanhado de Isidoro, seu escravo, Januário decide libertá-lo, mas o cativo recusa a alforria, "porque nem mais o seu nome ele [Januário] podia assinar", ${ }^{17}$ nem o nome lhe pertence. Uma vez morto em efígie, o réu é imediatamente destituído de tudo, inclusive e principalmente de seu corpo, pois poderia ser assassinado a qualquer momento e por qualquer um, afinal já estava mesmo morto. E aquele que o matasse "de novo" seria estimado até pelo rei. Enquanto o réu seria digno da vergonha da pena de ter sido executado em efígie e da ousadia de ainda estar vivo, apesar de morto.

Retomando ainda uma vez as epígrafes que estão postas antes do início da narrativa: na terceira, retirada da Vida e morte do bandeirante, de Alcântara Machado, se anuncia uma sentença, na qual se diz que o réu "é relaxado em estátua". ${ }^{18}$ Finalmente, a quarta epígrafe, do Diccionario da lingua portugueza, explica o significado de "relaxado", da anterior:

[...] os réos impenitentes, e obstinados ao braço ou à justiça secular; (ant.) entregar os táes a Inquisição, aos tribunaes seculares depois de terem sido por ella torturados e condemnados, para lhes serem impostas as penas de sangue e morte. ${ }^{19}$

16. VASCONCELOS apud DOURADO. Os sinos da agonia, p. 7.

17. DOURADO. Os sinos da agonia, p. 32.

18. MACHADO apud DOURADO. Os sinos da agonia, p. 7, grifo do original.

19. RELAXADO apud DOURADO. Os sinos da agonia, p. 7. 
Aqui, além da morte já sentenciada nas epígrafes anteriores, há um acréscimo: a tortura. Januário não é fisicamente supliciado, mas o é psicologicamente. Vivo ainda, sabe-se morto. As epígrafes parecem estar fora de lugar, porque o leitor que desconheça o conteúdo do romance poderá não compreendê-las. Mas a sua presença antecipa a morte em efígie de Januário, assim como a morte em efígie em si é uma antecipação da morte real. Além de pontuarem a prática como corrente, antiga e ao mesmo tempo contemporânea no Brasil colonial.

Januário terá acesso à própria morte, a morte em efígie, por meio da memória e da imaginação de Isidoro, seu escravo, e também pela memória que tinha de enforcamentos que ele mesmo presenciara. Ou seja, o rapaz (re) constrói a morte em efígie dele como um duplo, ou como um múltiplo, porque a cena se repete diversas vezes em seu pensamento. A consequência mais evidente dessa repetição, que vem filtrada e ao mesmo tempo colorida pela memória e imaginação, são as versões diferentes de uma mesma cena. Essa mistura - mais mistura, como no deus Jano - é nítida em diversas passagens e gera algumas confusões, como são confusas as ideias do rapaz:

Com toda essa matéria sonhada ou vivida, Januário rememorava o que os olhos não viram, o coração não sentiu. Tudo aquilo que o preto procurava, impotente e parco de palavras, lhe comunicar. Como se pintasse o painel da sua própria morte: e na verdade o era, sentia. Sentindo antecipadamente no pescoço o golpe, o peso do carrasco que lhe saltou nas costas. E de relance, num clarão, viu:

Aquele mesmo Mulungu [o carrasco] empurrou o condenado para fora do tablado. O corpo se esticando num baque, a corda presa na trave, balangou para um lado e para o outro, girando num movimento pendular, as pernas soltas e desamparadas. De um salto o carrasco foi se esganchar nas costas do enforcado, cavalgando-o, para a morte ser mais ligeira, ou de puro divertimento, nunca se sabe. ${ }^{20}$

Essa é a descrição de um enforcamento. Na verdade, essa é a descrição de uma versão de um enforcamento, porque algumas linhas abaixo, na mesma página, outra versão se apresenta ao leitor:

Ao contrário do que se esperava, o carrasco Mulungu não empurrou o corpo para fora do tablado, cavalgando-o; ao contrário: puxou com força

20. DOURADO. Os sinos da agonia, p. 45-46. 
a corda para trás, e o boneco de palha ficou suspenso lá no alto, junto de uma roldana.

Duas versões do mesmo episódio postas em sequência aproximam notadamente Januário do deus Jano. Jano também poderia ver os dois lados de um mesmo problema. Mas, como já foi salientado, Jano é um deus, Januário é um mero mortal. A duplicidade que em Jano seria mais um exercício de sabedoria, em Januário significa confusão. Januário deixa até mesmo o leitor em dúvida. Qual a cena que teria ocorrido de fato? A do carrasco pulando nas costas do condenado por diversão - numa atitude digna de uma farsa? Ou a segunda cena descrita, em que o carrasco se apresenta de forma sóbria e séria? O leitor jamais saberá ao certo. Isso porque, no fundo, nem Januário sabe ou quer saber. Quando o rapaz tem acesso às diferentes versões da própria morte ou mesmo as inventa, ele está e não está querendo chegar aos fatos propriamente ditos, isso porque:

[...] o presente seria por demais inquietante se fosse apenas imediato e primeiro: ele só é acessível pelo viés da representação, portanto, segundo uma estrutura iterativa que o assimila a um passado ou a um futuro graças a um ligeiro deslocamento que corrói o seu intolerável vigor e só permite sua assimilação sob a forma de um duplo mais digerível que o original na sua crueza primeira. ${ }^{22}$

É assim que Januário consegue manter a morte mais ou menos distante por algum tempo, porque ou ela está no passado, na morte em efígie que já passou, ou está no futuro, um momento que ainda não existe. Januário está foragido, vive escondido há um ano, enquanto está sendo caçado por todos. Seu mergulho na morte do boneco de palha é duro, mas ainda é a morte do outro que ele pensa não ser a dele. Mas quanto mais o tempo passa, mais Januário se aproxima da eliminação do duplo e da própria morte. O boneco morto protege Januário de morrer, mas só por um período. O rapaz acabará por reconhecer que "morto" o seu duplo só lhe resta fazer o mesmo.

De ambas as cenas da(s) morte(s) acima enunciadas, emerge o boneco de palha "morto", suspenso no ar. O boneco "morre" no lugar de Januário e Januário "vive" no lugar do boneco "morto", um está ocupando o lugar do outro. E mais, o boneco é Januário e Januário é o boneco. O boneco é matéria inerte, feito de capim, capim seco, palha, como informa a narrativa:

21. DOURADO. Os sinos da agonia, p. 46.

22. ROSSET. O real e seu duplo: ensaio sobre a ilusão, p. 46. 
Em cima da carreta, numa cadeira-de-estado alta, para que melhor se equilibrasse amarrado e não caísse aos solavancos das rodas nas pedras do calçamento, um enorme boneco de capim, do tamanho mesmo de um homem, a que tiveram o macabro cuidado de vestir a alva dos penitentes. No pescoço do calunga, o baraço $[\ldots]^{23}$

"Calunga" - boneco pequeno - é uma palavra que anda com frequência na boca de Isidoro, o escravo de Januário. Usando-a com aparente displicência, o cativo provoca e manipula o medo de Januário:

Se a gente pega um boneco, seja um calunguinha, e faz com ele toda sorte de maldade, pensando e dizendo que o calunguinha é a pessoa que a gente deseja tudo de ruim pra ela, se a gente espeta ou fura com faca ou punhal, mesmo a pessoa longe começa a espernear e a sofrer, a sangrar e a morrer, igual o calunguinha. ${ }^{24}$

É o mesmo Isidoro quem conclui,

[...] quando o preto Mulungu [o carrasco] puxou o grande calunga que o Capitão-General mandou enforcar [,] Nhonhô estava morto, era questão de mais dia menos dia. Era só entregar o corpo $[. . .]^{25}$

Ao olharmos com atenção para a narrativa, percebemos que há muito desse calunga, desse boneco, em Januário muito antes da cena da morte em efígie. Aliás, o que provoca a morte em efígie de Januário é exatamente o fato de ele ter sido o boneco de Malvina. Nas mãos ágeis e hábeis dela, Januário fora reduzido a um mero calunga; ela fez dele tudo o que quis. Malvina seduziu Januário e fez dele seu amante para causar ciúmes em Gaspar. Ou seja, Januário era o amante falso, porque estava no lugar do amante realmente desejado. Malvina decidiu matar o próprio marido e tomou seu boneco Januário para fazer o serviço sujo.

23. DOURADO. Os sinos da agonia, p. 42.

24. DOURADO. Os sinos da agonia, p. 47.

25. DOURADO. Os sinos da agonia, p. 47-48. 


\section{O soberano e o homo sacer}

A partir de estudos feitos por Kantorowicz e Giesey, Giorgio Agamben, em Homo sacer (2010), tece uma exposição sobre a morte em efígie do soberano. O autor descreve sucintamente situações nas quais um rei ou um imperador, após a morte, era duplicado por meio de uma efígie de cera. Esse boneco recebia por alguns dias o mesmo tratamento, inclusive médico e espiritual, aplicado ao soberano quando moribundo. Agamben observa que a primeira conclusão a que aqueles estudiosos chegaram sobre o caso é "que a presença da efígie devia ser relacionada [...] com a perpetuidade da dignidade real, que "não morre jamais",. ${ }^{26}$ Todavia, o esforço de Agamben vai além dessa percepção mais imediata e se dirige para uma aproximação do corpo do rei de outro corpo, o do homo sacer.

Antes de acompanharmos esse raciocínio, é preciso esclarecer o que seja o homo sacer. O conceito se refere a "uma pessoa [que] é simplesmente posta para fora da jurisdição humana sem ultrapassar para a divina", ${ }^{27}$ ou seja, é abandonada à própria sorte. Uma vez perdido o estatuto de humano, o bomo sacer torna-se insacrifícável e matável. ${ }^{28}$ Qualquer um pode matá-lo sem que se cometa homicídio. Já se vê aí que Januário corresponde de forma precisa a essa definição. Ele também foi abandonado e sua morte não é um crime; ele é apenas morto, executado no meio da rua por um soldado qualquer. Além disso, é preciso acrescentar que não se pode confundir o ritual grandioso da morte em efígie com a morte nua e crua de Januário propriamente dita, à qual são reservados dois ou três parcos parágrafos. Ao voltar à cidade, o rapaz vai até a praça, o mesmo local que fora cenário da sua morte em efígie, quando é reconhecido pelos soldados:

Januário finge que vai correr, ou vai mesmo correr. Queria ser morto de vez, não ia ser preso. Para um soldado mais afoito atirar. O soldado corre para ele, grita para. Januário não parou. O soldado é que para, atirou. Quase ao mesmo tempo: o estrondo, o baque na nuca. Januário caiu de borco no chão.

Os soldados correram para junto do corpo caído. Outro tiro, agora à queima-roupa. Mais outro. Chega, disse o alferes virando com a bota o corpo no chão, para que todos vissem a cara. E como um soldado pardo

26. AGAMBEN. Homo sacer. o poder soberano e a vida nua, p. 94.

27. AGAMBEN. Homo sacer. o poder soberano e a vida nua, p. 83.

28. AGAMBEN. Homo sacer. o poder soberano e a vida nua, p. 17. 
ainda fizesse tenção de atirar, eu disse chega, carece de tiro mais não! Está morto, olhem os olhos esbugalhados, a boca escumando sangue! $!^{29}$

O excesso de tiros é totalmente desnecessário porque, como declara o alferes em seguida: "Faz tempo que ele estava morto. Mesmo antes da gente atirar". ${ }^{30}$ Ou, como afirma Rosset, "todo acontecimento implica a negação do seu duplo". A morte de Januário elimina a morte do boneco - que na verdade ele era.

Retomando a aproximação entre o soberano que teve seu corpo duplicado por uma efígie de cera e o corpo do homo sacer, primeiramente Agamben coloca entre ambos o devoto. O devoto funciona como uma espécie de degrau intermediário para explicar as imbricações existentes entre eles. Quando o devoto consagra a própria vida aos deuses para salvar a cidade de um grande perigo e não morre, a comunidade é posta numa situação embaraçosa. ${ }^{32}$ Então, é preciso oferecer algo em troca aos deuses: uma imagem de sete pés, um colosso, é confeccionada e enterrada no lugar do devoto. No entanto, o colosso não é um substituto simples: "ele representa, analogamente ao cadáver, mas de modo mais imediato e geral, aquela parte da pessoa viva que é destinada à morte e que, ocupando ameaçadoramente o limiar entre os dois mundos, deve ser separada do contexto normal dos vivos" (p. 99).

Enquanto o devoto e o soberano são duplicados em efígies, "o homo sacer é, por assim dizer, uma estátua viva, o duplo ou o colosso de si mesmo" (p. 100). Ele é sozinho e integralmente aquela parte da pessoa viva que é destinada à morte. O que une o soberano, o devoto e o homo sacer é que todos eles tiveram "uma vida nua que foi separada de seu contexto" (p. 100). A vida nua corresponde a uma vida sem valor ou indigna de ser vivida (p. 135). É ainda Agamben (p. 9 e subsequentes) quem explica que essa hierarquização não é recente. Desde os gregos antigos houve uma divisão que classificava a vida em duas categorias: bíos e zoé. A primeira corresponderia ao cidadão e a segunda à vida nua, a vida de qualquer ser vivente, do animal e de todo aquele que não fosse considerado cidadão. Segundo o autor, quem define se uma vida é ou não digna de ser vivida é o poder soberano (p. 138); logo, a questão não é ética, e sim política (p. 137).

29. DOURADO. Os sinos da agonia, p. 332.

30. DOURADO. Os sinos da agonia, p. 332.

31. ROSSET. O real e seu duplo: ensaio sobre a ilusão, p. 36.

32. AGAMBEN. Homo sacer. o poder soberano e a vida nua, p. 97. 
Portanto, o que aproxima e distancia o devoto, o soberano e o homo sacer é que, para

[...] o devoto sobrevivente, o funeral imaginário funciona como um cumprimento vicário do voto, que restitui o indivíduo à vida normal; para o imperador, o funeral duplo permite fixar a vida sacra que deve ser recolhida e divinizada na apoteose; no homo sacer, enfim, nos encontramos diante de uma vida nua residual e irredutível, que deve ser excluída e exposta à morte como tal, sem que nenhum rito e nenhum sacrifício possam resgatá-la. (p. 100).

A morte em efígie corresponde ao momento em que Januário se aproxima de Jano, por causa da duplicidade, e também se torna homo sacer, matável. Mas é porque ele já era homo sacer que sofreu a morte em efígie. Um homem livre, sem recursos próprios, mestiço e vivendo numa sociedade patriarcal e escravocrata altamente estratificada é um bode expiatório fácil. De maneira que a morte em efígie é mais condizente com o homo sacer do que com Jano. No fundo, a aproximação entre Januário e Jano que Os sinos da agonia promove é enganosa e irônica, um simulacro. Segundo Baudrillard: "Dissimular é fingir não ter o que se tem. Simular é fingir ter o que não se tem". Adaptando a citação ao romance: simular é fingir ser o que não se é. Januário é uma personagem construída para simular ser Jano, mas ele evidentemente não é um deus, ele é um homo sacer, um matável. Apesar de Agamben não fazer uma relação entre tal categoria e a efígie, esse é sem dúvida o caso de Januário. Ele é o homo sacer que teve seu fim antecipado por uma morte em efígie. O calunga que fizeram para substituí-lo expõe a sua vulnerabilidade, a sua vida nua. Para a comunidade de Vila Rica, Januário é pura zoé. E por isso se faz dele um boneco - e boneco no duplo sentido, porque um boneco é feito para representá-lo e porque ele já era manipulado como um muito antes da pantomima do enforcamento.

É preciso ainda fazer com que os corpos do soberano e o do homo sacer se encontrem e se reflitam no do rei e no de Januário. Agamben salienta que o soberano e o homo sacer compartilham do fato de as suas mortes não configurarem homicídio. O assassinato do soberano constitui um "delito especial", ${ }^{34}$ definido como crimen lesae maiestatis, e como tal não é julgado por leis comuns destinadas ao controle e à punição de sujeitos igualmente comuns.

33. BAUDRILLARD. Simulacros e simulação, p. 9.

34. AGAMBEN. Homo sacer: o poder soberano e a vida nua, p. 102. 
Ora, é exatamente um suposto crime de lesa-majestade que condena Januário à morte. Não bastasse o aspecto social explícito na mestiçagem, existe também o político. Na verdade, tanto a mestiçagem quanto o crime de lesa-majestade condenam Januário a ser um homo sacer. Sempre equivocado, o rapaz pensa, a princípio, ter sido preso por roubo. O assassinato de João Diogo teria sido consequência de um suposto roubo e naturalmente um agravante. Porém, o Capitão-General se aproveita da situação e lhe dá uma dimensão bem maior, ressaltando os serviços prestados pela vítima a el-Rei e transformando assim um crime comum em um crime de lesa-majestade.

A narrativa ficcional se sobrepõe à histórica. As alusões à Inconfidência são evidentes, mas surgem como inventadas. Não haveria um motim de fato. Ou melhor, se havia um, o Capitão-General criou outro, um outro que ele pudesse controlar. É assim que um crime aparentemente irrelevante para os negócios de Estado assume o papel central num levante inventado pelo mesmo Estado, cujo representante é o Capitão-General. De forma que o poder soberano teria criado os problemas que ele próprio resolveria para então justificar a derrama - episódio que não pertence ao romance.

Portanto, o Capitão-General faz da morte em efígie uma cerimônia "aparatosa, lúgubre e exemplar. Com isso querendo atemorizar os povos das Minas e fazer ainda mais temida e respeitada a sua autoridade, para ganho e glória de Sua Majestade Real". 35 O que se expia na morte em efígie é muito mais do que um crime ordinário ou comum, trata-se de um crime de lesa-majestade. À grandiosidade do suposto feito de Januário deve corresponder uma punição exemplar. Todos deveriam ver na cerimônia do enforcamento o seu próprio enforcamento e sentir o mesmo medo que sentiriam se vivessem isso um dia. O boneco não está simplesmente no lugar de Januário, mas está no lugar de todos aqueles que poderiam vir a se insurgir contra o poder soberano: "O próprio Capitão-General, o próprio Vice-Rei, cada um queria ser mais zeloso nos negócios del-Rei. Eles estavam loucos por um bode expiatório, para exemplar. Careciam de uma vítima, para melhor poderem fazer a cobrança dos quintos". ${ }^{36}$ É o que explica o pai a um Januário pasmo diante dessa verdade inventada a partir do assassinato do seu rival amoroso. De maneira que não é só o boneco que está no lugar do rapaz, também novas histórias são inscritas umas sobre as outras.

35. DOURADO. Os sinos da agonia, p. 37.

36. DOURADO. Os sinos da agonia, p. 68. 


\section{Considerações finais}

Filho de pai branco e mãe índia, Januário é um sem-lugar. Deslocado, ele será sempre um bastardo para a família do pai. Morto em efígie pelo assassinato de João Diogo, Januário só faz salientar a ilegitimidade da sua condição. Quem morreu não foi o rapaz, foi um boneco, mas morto o boneco, ele está morto para todos - morto de vez, porque na condição de bastardo ele estava à margem daquela sociedade desde sempre. Qualquer um pode matá-lo sem culpa nem pena, pois a lei já o executou. E o boneco que o Capitão-General fez era a representação de um outro que lhe foi anterior. A participação de Januário no assassinato de João Diogo fora de mero boneco de Malvina; foi ela quem articulou a morte do marido. Mas esse boneco tosco que Malvina manipula não é outro senão aquele em que o próprio Januário permitiu ser transformado. Januário viveu como boneco nas mãos de Malvina e como boneco morreu. Afinal, como explica Rosset, há um "terror mais profundo: de eu mesmo não ser aquele que pensava ser. E, mais profundamente ainda, de suspeitar nesta ocasião que talvez não seja alguma coisa, mas nada". ${ }^{37}$ É esse terror que faz ou que permite que Januário se duplique e, consequentemente, se anule. Não é à toa que o rapaz passará a maior parte da narrativa acuado no alto da serra de Ouro Preto: das margens da cidade ele olha, nas margens ele passou sua vida.

O duplo é repetição, mas também é diferença. Januário repete o mítico deus Jano, já em seu nome: Jano-Janus-janeiro-Januário. Januário, como Jano, vê em todas as direções, mas o que é qualidade no deus é excesso para o mortal. Ver em todas as direções para o deus Jano significa sabedoria e capacidade de discernimento. Ver para Jano significa saber. Ver em todas as direções para Januário significa dúvida e confusão, pois ele vê tudo o que Malvina faz, mas não consegue agir. Januário passa a maior parte do tempo sem compreender, é apenas um boneco nas mãos brancas e macias da moça. Quando ele finalmente compreende o papel marginal que ocupara na vida da amante, é tarde demais. Quando Januário deixa de ser o boneco de Malvina, ele já está morto, só lhe resta entregar o corpo, como há muito Isidoro profetizara: "Nhonhô estava morto, era questão de mais dia menos dia. Era só entregar o corpo...." É Ex exatamente o que Januário faz na última cena do romance, quando, um ano depois, vai/ volta à praça onde o boneco fora "morto". Pela última vez, Januário troca de lugar com o boneco, o lugar que já era dele, o de morto.

37. ROSSET. O real e seu duplo: ensaio sobre a ilusão, p. 66.

38. DOURADO. Os sinos da agonia, p. 47-48. 
É como esse boneco que era antes de ser morto, como boneco e como mestiço, que Januário se revela um homo sacer, insacrificável e matável. A morte aparatosa e ritualizada fora reservada à efígie, não a ele. A Januário cabem uns tiros dados pela soldadesca, sem pompa, nem festa. Afinal, "Faz tempo que ele estava morto. Mesmo antes da gente atirar". 39

Januário: Janus or Homo Sacer

Abstract: From the episode of the death of the character in effigy Januario, in Os Sinos da Agonia (1974), a novel by Autran Dourado, this paper discusses aspects related to the double, mainly from the perspective of Clément Rosset and Gilles Deleuze. Questioning the more or less evident approximation between the young man and the god Janus of Roman mythology, this paper presents Januário as a homo sacer in the sense that Giorgio Agamben gives to that expression in the homonymous book. The homo sacer is an unsacrificeable and killable person. Thus, it is possible to say that Januário dies in effigy because he is abandoned by society and society abandons him in order to kill him.

Keywords: Os Sinos da Agonia, Double, Homo sacer.

$$
\text { Referências }
$$

ABREU, Capistrano de. Capítulos de história colonial apud DOURADO, Autran. Os sinos da agonia. 4. ed. Rio de Janeiro: Rocco, 1999.

AGAMBEN, Giorgio. Homo sacer o poder soberano e a vida nua. Tradução de Henrique Burigo. 2. ed. Belo Horizonte: Editora UFMG, 2010. v. 1.

BAUDRILLARD, Jean. Simulacros e simulação. Tradução de Maria João da Costa Pereira. Lisboa: Relógio D’Água, 1991.

DELEUZE, Gilles. Diferença e repetição. Tradução de Luiz Orlandi e Roberto Machado. Lisboa: Relógio D’Água, 2000.

DOURADO, Autran. Os sinos da agonia. 4. ed. Rio de Janeiro: Rocco, 1999.

FAUSTINO, Raquel. A origem do universo em Ovídio. Língua, Literatura e Ensino, Campinas, v. 4, p. 259-269, maio 2009. Disponível em: <http://www.iel.unicamp.br/ revista/index.php/lle/article/view/756>. Acesso em: 21 mar. 2013.

39. DOURADO. Os sinos da agonia, p. 332. 
GRIMAL, Pierre. Dicionário da mitologia grega e romana. Tradução de Victor Jabouille. 4. ed. Rio de Janeiro: Bertrand Brasil, 2000.

MACHADO, Alcântara. Vida e morte do bandeirante apud DOURADO, Autran. Os sinos da agonia. 4. ed. Rio de Janeiro: Rocco, 1999.

RELAXADO. In: SILVA, António de Morais. Diccionario da lingua portugueza apud DOURADO, Autran. Os sinos da agonia. 4. ed. Rio de Janeiro: Rocco, 1999.

ROSSET, Clément. O real e seu duplo: ensaio sobre a ilusão. Tradução de José Thomaz Brum. Porto Alegre: L\&PM, 1988.

VASCONCELOS, Diogo de. História antiga das Minas Gerais apud DOURADO, Autran. Os sinos da agonia. 4. ed. Rio de Janeiro: Rocco, 1999. 